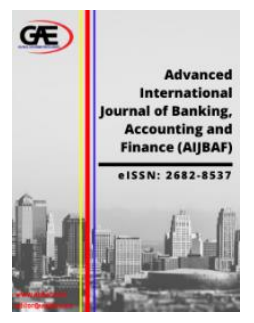

\author{
ADVANCED INTERNATIONAL JOURNAL OF \\ BANKING, ACCOUNTING AND FINANCE \\ (AIJBAF) \\ www.aijbaf.com
}

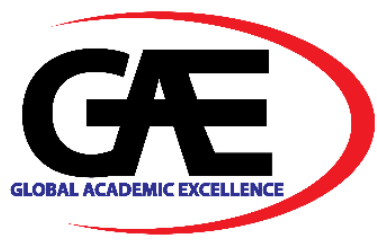

\title{
NON-SHARIAH COMPLIANCE OF ISLAMIC BANKS AND CUSTOMERS COMMITMENT: TRUST AS MEDIATOR
}

\author{
Muhammad Usman ${ }^{1 *}$, Anwar Allah Pitchay ${ }^{2}$, Munazza Zahra ${ }^{3}$ \\ 1 School of Management, Universiti Sains Malaysia \\ Email: muhammad_usman@student.usm.my \\ 2 School of Management, Universiti Sains Malaysia \\ Email: anwaap@usm.my \\ 3 School of Management, Universiti Sains Malaysia \\ Email:munazza.zahra89@gmail.com \\ * $\quad$ Corresponding Author
}

\section{Article Info:}

Article history:

Received date: 03.08.2021

Revised date: 15.08 .2021

Accepted date: 30.08 .2021

Published date: 01.09.2021

\section{To cite this document:}

Usman, M., Pitchay, A. A., \& Zahra, M. (2021). Non-shariah Compliance of Islamic Banks and Customers Commitment: Trust as Mediator. Advanced International Journal of Banking, Accounting, and Finance, 3 (8), 28-36.

DOI: 10.35631/AIJBAF.38003.

This work is licensed under $\mathrm{CC}$ BY 4.0

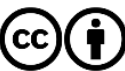

\section{Abstract:}

The purpose of this paper is to find out the impact of non-shariah compliance (NSC) of Islamic banks on the commitment of the customers and the role of trust as a mediator. The paper uses a quantitative approach by using surveys to collect data from 276 respondents. Smart PLS was used to run the analysis. Non-compliance of Islamic financial institutions with shari'ah principles significantly affects the commitment of the customers. Results of this showed that trust significantly impacts the commitment of the customers, study also indicated that trust mediates the relationship between the commitment and noshari'ah compliance.

Keywords:

Non- Shari'ah Compliance, Islamic Banks, Customers, Trust, Commitment 


\section{Introduction}

Non-compliance to shariah (NCS) principles by Islamic financial institutions significantly impacts customer's commitment. The belief of a customer to find services from a provider is what defines trust. In Islamic financial institutions, trust constitutes a belief that the banks are managed according to sharia principles and are different from the regular banks. Clients decide to use Islamic banks due to their need to undertake economic activities based on shariah principles. Islamic banks provide an opportunity for the public to undertake banking activities based on shariah principles which advocate for zero usury, free uncertainty, and no gambling (Maghfuriyah et al., 2019). In Pakistan, Islamic financial institutions are rapidly growing, with a share capital of $18.1 \%$ of the overall banking industry in the country (Shaikh, 2018). However, clients' commitments to the Islamic banks are impacted by the enterprise's inability to comply with sharia principles. Trust as a variable mediates the impact of non-sharia compliance of Islamic financial enterprises on customer's commitments.

\section{Literature Review}

\section{Non-shariah Compliance}

Any activity/operation which is against/violates shariah principles set by the shari'ah committee is considered as "non-shari' ah compliance" (NSC).

"An institution shall at all times ensure that its aims and operations, business, affairs, and activities are in compliance with Shariah." (IFSA 2013)

As a result, the IFI must adhere to Shariah law in all of its operations, activities, transactions, and action by adhering to the Shariah committee and its Shariah standards, ensuring internal policies and processes are Shariah-compliant, and establishing a Shariah audit function. (Mohamad Akram Laldin and Hafas Furqani 2018). However, it cannot be ignored that IFIs are constantly exposed to Shariah non-compliant circumstances, which have failed to meet duties or satisfy Shariah requirements as stipulated in the relevant jurisdiction's standards (Romzie Rosman, Anna Che Azmi, Siti Noraini Amin, 2017). According to the Tabrani, Amin, and Nizam (2018) trust leads to a high degree of commitment; the more and more consumers trust, the more dedicated they are. Within the context of IB, most studies find that customers trust Islamic banks because they are committed to putting their principles into practice (Houjeir \& Brennan, 2017; Usman et al., 2017)

\section{Commitment}

The concept of commitment, which has played an important part in service marketing, is heavily reliant on the relationship between the company and its customers (Chai, Malhotra, \& Dash, 2015; Fullerton, 2003; Garbarino \& Johnson, 1999; Moorman, Deshpande, \& Zaltman, 1993; Moorman, Zaltman, \& Deshpande, 1992; Morgan \& Hunt, 1994). Commitment and trust are two essential elements in the development of a relationship. According to the Morgan and Hunt (1994), commitment is defined as "an exchange partner who feels that their ongoing connection with another is valuable enough to justify their best efforts to sustain it.". On the other hand, Moorman et al. (1992), defines Commitment as "a continuing desire to maintain valued relationships with their clients". These definitions fundamentally include an emotional bond (Moorman et al., 1992; Morgan \& Hunt, 1994) which also include an expectation to receive a bigger advantage in case of maintaining a relationship (Chenet, Dagger, \& O'Sullivan, 2010; Geyskens, Steenkamp, Scheer, \& Kumar, 1996). Anderson and Weitz (1992); (CurrasPerez \& Sanchez-Garcia, 2016) concluded that a firm must establish a mutual commitment and Copyright $\odot$ C GLOBAL ACADEMIC EXCELLENCE (M) SDN BHD - All rights reserved 
Volume 3 Issue 8 (September 2021) PP. 28-36

DOI 10.35631/AIJBAF.38003

must concentrate on maintaining the relationship with customers so that firms shared values may develop.

Commitment is a key component in establishing a long-term partnership between parties. According to Revilla-Camacho, Cosso-Silva, and Palacios-Florencio (2017), it is advantageous to the company because customers have a high degree of loyalty, consider themselves to be business partners, and are thus encouraged to maintain a close partnership with the firm for a longer period of time. However, most of them suggested to quantify both definitions as unidimensional owing to the difficulties in recognising the theoretical basis of these two main concepts (trust and commitment) (Andaleeb, Rashid, \& Rahman, 2016; Dwyer, Schurr, \& Oh, 1987; Ganesan, 1994; Martn, Gutierrez, \& Camarero, 2004; Morgan \& Hunt, 1994). This research takes a one-dimensional view to the idea of dedication, which is reinforced by the literature (Anderson \& Weitz, 1992; Brock \& Zhou, 2012; Garbarino \& Johnson, 1999; Hennig-Thurau, Gwinner, \& Gremler, 2002; Ponder et al., 2016).

\section{Trust}

Trust is a dynamic concept that has been conceptualized in various ways (Amin, Isa, \& Fontaine, 2013; Lu, Fan, \& Zhou, 2016), resulting in much debate about its dimensions, antecedents, and consequences in business relationships (Toufaily \& Pons, 2017; Baumann \& Le Meunier-FitzHugh, 2014). Moorman et al. (1993) define trust as the willingness to put one's confidence in an exchange partner in whom one has confidence. Martin, K.D. and Murphy, P.E. (2017) see trust as a vital component in the interaction between people, organizations, and an individual and an organization. Previous research has looked into trust as an essential factor in determining the strength of a relationship (Baumann and Le Meunier-FitzHugh, 2014; Martin and Murphy, 2017; Ponder et al., 2016). Despite the fact that there is no consensus in the literature on the relationship between trust and commitment, several studies have found that trust is important in increasing customer commitment (Kassim and Abdulla, 2006; Moorman et al., 1992, 1993; Sharma et al., 2015; Shukla et al., 2016). Boateng and Narteh (2016), Cho and $\mathrm{Hu}$ (2009), Montazemi and Qahri-Saremi (2015), for example, state that when consumers engage in partnerships with their banks, they must trust them before committing to them.

Morgan and Hunt (1994) believe that commitment and trust are essential components of a strong partnership. Commitment and trust are two crucial components in developing a partnership. Morgan and Hunt (1994) describe commitment as "an exchange partner who believes that their continuing partnership with another is significant enough to justify their best efforts to sustain it." Commitment, on the other hand, is described by Moorman et al. (1992) as "a continuing commitment to establish cherished relationships with their clients." These meanings primarily involve relational bonds (Moorman et al., 1992; Morgan \& Hunt, 1994), as well as the hope of receiving a greater benefit if the partnership is maintained (Chenet, Dagger, \& O'Sullivan, 2010; Geyskens, Steenkamp, Scheer, \& Kumar, 1996). In order for a firm's common values to grow, Anderson and Weitz (1992); (Curras-Perez \& Sanchez-Garcia, 2016) concluded that a company must build a reciprocal interest and focus on retaining relationships with customers.

\section{Methodology}

Quantitative data for this research is obtained through a survey method in Pakistan. The area is chosen because of the rapid growth of Islamic banks. Pakistan has 21 total and fully-fledged Islamic banks providing services based on Islamic financial institutions (Shaikh, 2018). Copyright $\odot$ GLOBAL ACADEMIC EXCELLENCE (M) SDN BHD - All rights reserved 
Volume 3 Issue 8 (September 2021) PP. 28-36 DOI 10.35631/AIJBAF.38003

According to Shaikh (2018), the total assets of Islamic banks in Pakistan have indicated a growth of up to Rs. Two thousand eighty-three billion, thus showing an $11.7 \%$ quarterly increase.

The participants provided with survey questionnaires were 276 and mostly clients to the Islamic banks nearby. The number of males was 153, with 123 female participants. The participants selected were elderly, 45 years and above. The selection in age criteria was due to the need to get Islamic bank enterprises customers used to shariah compliance and are mature in religion.

The number of samples used for analysis was 205 from complete survey questionnaires filled by the customers, with 29 indicators as shown in Fig 1 below. The survey questions answer whether the non-compliance to sharia principles by Islamic banks impacts customers' commitment. The other question answered the impact of non-sharia compliance by Islamic banks to trust. The last question answers the possibility of trust to mediates the impact of nonsharia compliance on customers' commitment. Hypothetical questions result in the survey were analyzed with SmartPLS 3 software.

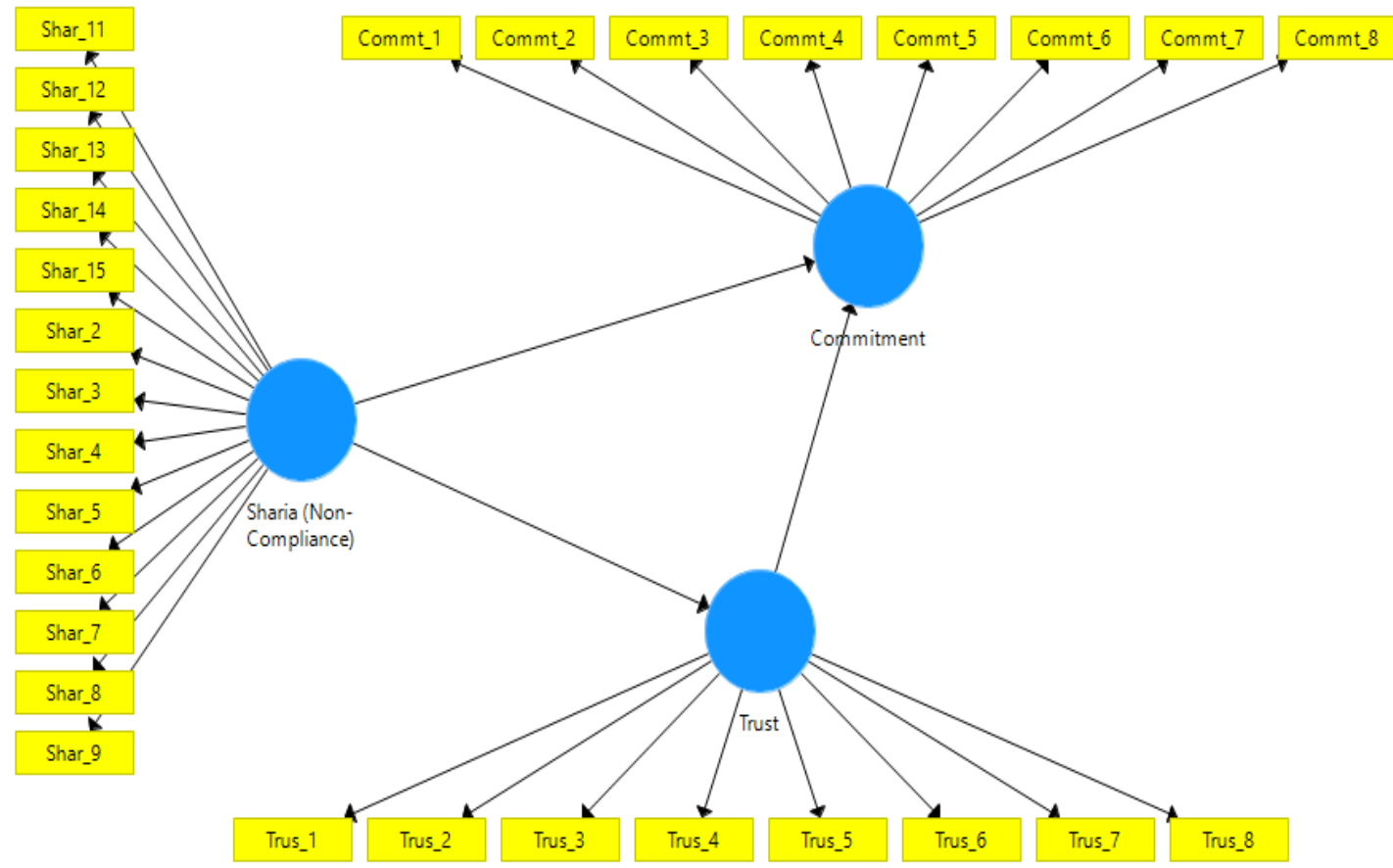

Figure 1: SmartPLS Processing Path Diagram of Each Variant and Indicator.

\section{Results}

\section{Description of Respondents}

The respondents in the study were Islamic bank customers in Pakistan, totaling 276, but the sample used for analysis was 205. The respondents were different in gender, with more males as compared to females. The respondents were Muslim, and therefore they were aware of shariah principle compliance. In addition, the respondents were 45 years and above; hence they were old and mature clients who are aware of what was going on. 


\section{Validity And Reliability of The Outer Model}

The amount of factor loading indicator to construct variables is used to test convergent validity. More than 0.7 AVE (average variant extracted) factor is considered acceptable, but 0.4 to 0.7 is still countable (Wahyoedi et al., 2021). Convergent validity is established from average extracted variant values. Analysis with SmartPLS shows that variables met the criteria for convergent test validity, as indicated in Table 1 below.

\section{Table 1: Variables Met Convergent Test Validity After Smartpls Processing}

\begin{tabular}{|l|r|r|r|} 
& Cronbach's Alpha & Composite Reliability & Average Variance Extracted (AVE) \\
\hline Commitment & 0.581 & 0.781 & 0.544 \\
\hline Sharia (Non-Compliance) & 0.594 & 0.787 & 0.553 \\
\hline Trust & 0.563 & 0.773 & 0.532 \\
\hline
\end{tabular}

The precision and accuracy of measurements were also established after several measurement subjects were tested and consistently got similar results. The internal reliability test result of Cronbach's and Composite are displayed in Table 1 above. The Composite reliability results were above 0.7 , and Cronbach's were above 0.5 in the reliability test as recommended by Hair (2017) hence attaining good consistency.

\section{Inner Model}

The coefficient of determination is commonly used to evaluate a structural model with R square values in the range of 0 to 1 . The highest level resembles a higher accuracy, and a weaker value indicates a weak prediction. Hair (2017) states that values between 0 to 0.5 are weak, and values above 0.5 are stronger.

Table 2: SmartPLS Processing of R Square Adjustment

\begin{tabular}{|l|c|c|} 
& R Square & R Square Adjusted \\
\hline Commitment & 0.348 & 0.344 \\
\hline Trust & 0.337 & 0.335
\end{tabular}

The values of 0.34 and 0.33 indicated in the table above are moving towards solid indicators and, therefore, are still applicable for predicting trust and commitment impacts by noncompliance to sharia principles by Islamic financial institutions (Wahyoedi et al., 2021). The variations can be accounted for by the variables that are not examined in this study.

\section{Hypothesis Testing}

The hypothesis testing using the SmartPLS was conducted to establish the direct impact of noncompliance of sharia principles by Islamic financial institutions on customer commitment and when mediated by trust. The direct impact is represented in table 3 , and the mediated is indicated in table 4. 
Table 3: Direct Impacts of Hypothesis Tests Analysis with SmartPLS

\begin{tabular}{|c|c|c|c|}
\hline & Sample Mean (M) & T Statistics $(|\mathrm{O} / \mathrm{STDEV}|)$ & P Values \\
\hline Sharia (Non-Compliance) -> Commitment & 0.236 & 1.516 & 0.130 \\
\hline Sharia (Non-Compliance) -> Trust & 0.785 & 17.394 & 0.000 \\
\hline Trust $->$ Commitment & 0.551 & 3.571 & 0.000 \\
\hline
\end{tabular}

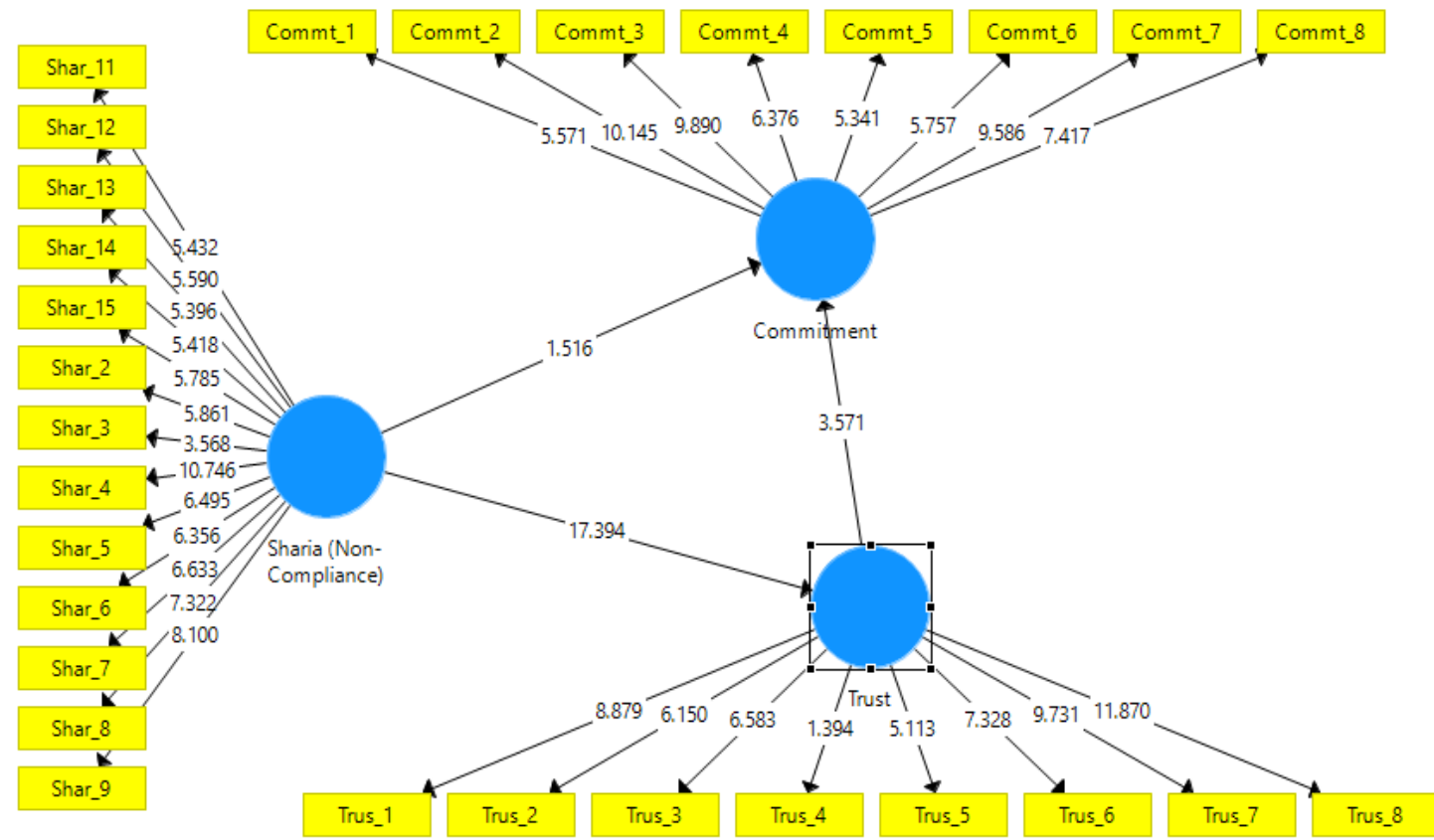

Figure 2: Path Diagram Representation of Hypotheses Test After SmartPLS Processing.

Table 4: Mediating Impacts Hypothesis Test Result with SmartPLS.

\begin{tabular}{|l|ccc} 
& Sample Mean (M) & TStatistics (|O/STDEV|) & P Values \\
\hline Sharia (Non-Compliance) -> Trust -> Commitment & 0.435 & 3.407 & 0.001 \\
\hline
\end{tabular}

Testing of mediating impact was essential in establishing the effect that a variable can cause after acting as a mediator on non-compliance of Islamic financial institutions to customers' commitment. Trust variable was tested as the mediating factor to sharia non-compliance impact of Islamic banks on customers commitment and result provided in table 4 above.

\section{Discussion}

\section{Impacts of Shariah Non-Compliance on Commitment}

Failure to comply with shariah principles by Islamic banks significantly impacts customers' commitment to the financial institution as indicated in Table 3 by a coefficient ratio of 0.236 with a value of $p$ as 0.130 which slightly exceeds the level of significance of 0.05 . The statistics indicate the positive effect that shariah principles compliance has on customers' loyalty to the financial institutions. The shariah compliance principles impact the ability of customers to remain committed to Islamic financial institutions. According to Wahyoedi et al. (2021), 
Volume 3 Issue 8 (September 2021) PP. 28-36 DOI 10.35631/AIJBAF.38003

customers of Islamic banks expect that these institutions will conduct their operations based on Shariah principles failure to which they will divert their commitment to other financial enterprises.

\section{Impacts of Shariah Non-Compliance on Trust}

Non-compliance to sharia principles by Islamic banks significantly impacts the trust of clients. The non-shariah compliance's impact on trust is shown in Table 2 by a coefficient ratio of 0.785 with the value of $\mathrm{p}$ as 0.000 . The statistical figure indicates that a client's trust in an Islamic bank is impacted by the institution's inability to comply with shariah principles. A customer's belief to find goods and services they want from a business entity is identified as trust (Maghfuriyah et al., 2019). Trust in Islamic banks is the belief that they comply with shariah standards hoping that they are not similarly managed as regular financial enterprises.

\section{Impacts of Trust on Customer Commitment}

The trust impact on customers' commitment due to non-shariah compliance of Islamic financial institutions is represented in Table 3 by a coefficient ratio of 0.551 with the value of $p$ indicated as 0.000 , which is lower than the level of significance at 0.05 . This statistic is a clear indication that trust issues significantly affect customer commitment to Islamic banks. The doubt posed by clients on a bank due to their inability to conform to the sharia principle is significant as they usually expect that banking with them is a way of promoting sharia compliance economic activity (Wahyoedi et al., 2021). When customers have trust in financial institutions, they will recommend customers to them and remain committed.

\section{Impact Of Non-Shariah Compliance on Customer Commitment Mediated by Trust}

The indirect effects of non-shariah compliance of Islamic banks on customer commitment when trust mediates are shown in Table 3 by a coefficient ratio of 0.435 with the value of $p$ as 0.001 , which is below the significance level of 0.05 . The impact of non-shariah compliance on customer commitment to Islamic banks is significant when mediated by the trust, as indicated in the statistical finding. A customer chooses a bank with an Islamic financial institution due to their need to grow a shariah-compliant economic activity (Wahyoedi et al., 2021). Customers decide to use Islamic financial institutions, hoping to undertake Islamic banking activities that comply with shariah principles.

\section{Conclusion}

Non-shariah compliance of financial entities based on Islamic beliefs significantly affects a client's commitment and trust. The impacts indicate that financial enterprises based on Muslim beliefs should comply with shariah principles and morals in undertaking economic activities. Trust significantly affects the commitments of Muslim clients to sharia non-compliant Islamic financial institutions. The trust that customers have to mediate the impact of non-compliance of Islamic financial institutions on their commitment to those banks. This study contributes to the need for continuous education on banking services provided by Islamic financial enterprises. This research further recommends studies on service quality, customer satisfaction, and sharia non-compliance in Islamic banks. 


\section{References}

Anderson, E., \& Weitz, B. (1992). The use of pledges to build and sustain commitment in distribution channels. Journal of marketing research, 29(1), 18-34.

Amin, M., Isa, Z. and Fontaine, R. (2013), "Islamic banks: contrasting the drivers of customer satisfaction on image, trust, and loyalty of Muslim and non-Muslim customers in Malaysia”, International Journal of Bank Marketing, Vol. 31 No. 2, pp. 79-97.

Sheena Lovia Boateng \& Bedman Narteh, 2016. "Online relationship marketing and affective customer commitment - The mediating role of trust," Journal of Financial Services Marketing, Palgrave Macmillan, vol. 21(2), pages 127-140

Baumann, J. and Le Meunier-FitzHugh, K. (2014), "Trust as a facilitator of co-creation in customer-salesperson interaction-an imperative for the realization of episodic and relational value?", AMS Review, Vol. 4 Nos 1/2, pp. 5-20.

Chai, J. C. Y., Malhotra, N. K., \& Dash, S. (2015). The impact of relational bonding on intention and loyalty. Journal of Hospitality and Tourism Technology, 6(3), 203.

Chenet, P., Dagger, T. S., \& O'Sullivan, D. (2010). Service quality, trust, commitment and service differentiation in business relationships. Journal of Services Marketing, 24(45), 336-345.

Curras-Perez, R., \& Sanchez-Garcia, I. (2016). Antecedents and consequences of consumer commitment in traditional and low-cost airlines. Journal of Travel \& Tourism Marketing, 33(6), 899-911.

Fullerton, G. (2003). When does commitment lead to loyalty? Journal of service research, 5(4), 333-344.

Garbarino, E., \& Johnson, M. S. (1999). The different roles of satisfaction, trust, and commitment in customer relationships. Journal of Marketing, 63(2), 70-87.

Geyskens, I., Steenkamp, J.-B. E., Scheer, L. K., \& Kumar, N. (1996). The effects of trust and interdependence on relationship commitment: A trans-Atlantic study. International Journal of research in Marketing, 13(4), 303.

Lu, B., Fan, W. and Zhou, M. (2016), "Social presence, trust, and social commerce purchase intention: an empirical research", Computers in Human Behavior, Vol. 56, March, pp. 225-237.

Laldin, M.A. and Furqani, H. (2018), "Islamic Financial Services Act (IFSA) 2013 and the Sharī'ah-compliance requirement of the Islamic finance industry in Malaysia", ISRA International Journal of Islamic Finance, Vol. 10 No. 1, pp. 94101. https://doi.org/10.1108/IJIF-12-2017-0052

Martin, K.D. and Murphy, P.E. (2017), "The role of data privacy in marketing", Journal of the Academy of Marketing Science, Vol. 45 No. 2, pp. 135-155

Mohamad Akram Laldin, Hafas Furqani. 2018. Islamic Financial Services Act (IFSA) 2013 and the Sharī ahcompliance requirement of the Islamic finance industry in Malaysia. ISRA International Journal of Islamic Finance, 94-101

Montazemi, A.R. and Qahri-Saremi, H. (2015), "Factors affecting adoption of online banking: a meta-analytic structural equation modeling study", Information \& Management, Vol. 52 No. 2, pp. 210-226.

Moorman, C., Deshpande, R., \& Zaltman, G. (1993). Factors affecting trust in market research relationships. Journal of Marketing, 57(1), 81-101.

Moorman, C., Zaltman, G., \& Deshpande, R. (1992). Relationships between providers and users of market research: The dynamics of trust within and between organizations. Journal of marketing research, 29(3), 314-328. 
Volume 3 Issue 8 (September 2021) PP. 28-36 DOI 10.35631/AIJBAF.38003

Morgan, R. M., \& Hunt, S. D. (1994). The commitment-trust theory of relationship marketing. Journal of Marketing, 58(3), 20-38.

Hair, J. F., Hult, G. T. M., Ringle, C. M., \& Sarstedt, M. (2017). A Primer on Partial Least Squares Structural Equation Modeling (PLS-SEM). 2nd ed., Thousand Oaks: Sage.

Houjeir, R., \& Brennan, D. (2017). The influence of culture on trust in B2B banking relationships. International Journal of Bank Marketing, 35(3), 495515. https://doi.org/10.1108/IJBM-05-2016-0075

Islamic Financial Services Act 2013 (Act 759).

Kassim, N.M. and Abdulla, A.K.M.A. (2006), "The influence of attraction on internet banking: an extension to the trust-relationship commitment model", International Journal of Bank Marketing, Vol. 24 No. 6, pp. 424-442.

Martin, K.D. and Murphy, P.E. (2017), "The role of data privacy in marketing", Journal of the Academy of Marketing Science, Vol. 45 No. 2, pp. 135-155.

Maghfuriyah, A., Azam, S. M. F., \& Shukri, S. (2019). Market structure and Islamic banking performance in Indonesia: An error correction model. Management Science Letters, 1407-1418. https://doi.org/10.5267/j.msl.2019.5.010

Ponder, N., Betsy, B.H. and Hansen, J.D. (2016), "The mediating effects of customers' intimacy perceptions on the trust-commitment relationship", Journal of Services Marketing, Vol. 30 No. 1, pp. 75-87.

Romzie Rosman, Anna Che Azmi, Siti Noraini Amin. 2017. Disclosure of Shari'ah noncompliance income by Islamic banks in Malaysia and Bahrain. International Journal of Business and Society, 45-58.

Sharma, N., Young, L.C. and Wilkinson, I. (2015), "The nature and role of different types of commitment in inter-firm relationship cooperation", Journal of Business \& Industrial Marketing, Vol. 30 No. 1, pp. 45-59.

Shaikh, S. A. (2018). Role of Islamic banking in financial inclusiveness in Pakistan: promise, performance, and prospects. International Journal of Financial Services Management, 9(1), 88. https://doi.org/10.1504/ijfsm.2018.089933

Shukla, P., Banerjee, M. and Singh, J. (2016), "Customer commitment to luxury brands: antecedents and consequences", Journal of Business Research, Vol. 69 No. 1, pp. 323331.

Usman, H., Tjiptoherijanto, P., Balqiah, T.E. and Agung, I.G.N. (2017), “The role of religious norms, trust, importance of attributes, and information sources in the relationship between religiosity and selection of the Islamic bank", Journal of Islamic Marketing, Vol. 8 No. 2, pp. 158-186.

Toufaily, E. and Pons, F. (2017), "Impact of customers' assessment of website attributes on erelationship in the securities brokerage industry: a multichannel perspective", Journal of Retailing and Consumer Services, Vol. 34, January, pp. 58-69

Wahyoedi, S., Sudiro, A., Sunaryo, S., \& Sudjatno, S. (2021). The effect of religiosity and service quality on customer loyalty of Islamic banks mediated by customer trust and satisfaction. Management Science Letters, 187-194. https://doi.org/10.5267/j.msl.2020.8.016 